\title{
Slow growth of Antarctic bryozoans increases over 20 years and is anomalously high in 2003
}

\author{
David K. A. Barnes ${ }^{*}$, Karen Webb, Katrin Linse \\ British Antarctic Survey, Natural Environment Research Council, High Cross, Madingley Road, Cambridge CB3 0ET, UK
}

\begin{abstract}
Some organisms are particularly appropriate models for investigation of variability in time and space for given environments. The erect bryozoan Cellarinella nutti, an endemic Antarctic species, is one such organism: it is extremely abundant, occurs from the polar front to the Antarctic continental edge, and preserves a clear macroscopic environmental record in its skeleton (growth check lines). We studied variability in the growth of 93 C. nutti individuals at depths between 247 and $414 \mathrm{~m}$, at sites 1, 10, 100 and $>1000 \mathrm{~km}$ apart in the Weddell Sea, Antarctica. Trawled C. nutti varied from 5 to $23 \mathrm{yr}$ in age, and nearly half the colonies had grown asexually from fragments. We measured the annual growth increments, which ranged from $\sim 18$ zooids ( $8.6 \mathrm{mg}$ dry mass, $0.8 \mathrm{mg}$ ash-free dry mass; Age 1) to 130 zooids (43 mg dry mass, $2.48 \mathrm{mg}$ ash-free dry mass; Age 20). At 9 yr (the modal age), each $C$. nutti individual had precipitated $>182 \mathrm{mg} \mathrm{CaCO}_{3}$, and by $20 \mathrm{yr}$ nearly $580 \mathrm{mg}$. C. nutti grows slowly compared with other erect bryozoans, even those in the Antarctic. We found colony and site to be insignificant factors in its growth, despite the large range of distances between sites, but year was highly significant. We found a non-linear increase in growth spanning the last 2 decades that has no obvious relation to El Niño Southern Oscillation (ENSO)-associated environmental fluctuations. In particular we found that growth in 2003 was greater than in any other year measured by a factor of 2. Given its abundance, longevity, ubiquity in Antarctic waters, insignificant spatial variability in growth, but distinct annual variability, C. nutti may prove to be an important species to investigate whether benthic organisms, as well as krill, salps and fur seals, are beginning to develop major climate-related changes in phenology.
\end{abstract}

KEY WORDS: Climate change - Weddell Sea - Benthic organisms $\cdot$ Check-lines $\cdot$ Southern Ocean · $\mathrm{CaCO}_{3}$

\section{INTRODUCTION}

Organisms strongly reflect their environment, sometimes recording changes from the largest evolutionary to the smallest ecological time scales. For example, the distributions of biota contracted to refugia, and subsequently expanded across continental shelves, mirroring the wax and wane of ice sheets over the last 2 million years between glacial maxima and minima (Williams et al. 1998, Hodgson et al. 2001). Whilst the palaeogeography of some organisms may reflect such Milankovitch 41 kyr (kyr = 1000 yr) and 100 kyr cycles, the recent and current biogeography of others (e.g. corals) are strong indicators of environmental change on ecological time scales (see Jackson et al. 2001).
Tidal, daily, seasonal and annual rhythms are now known to be reflected in a wide variety of metazoans, but longer fluctuations following El Niño Southern Oscillation index (ENSO), decadal or climate warming scales have also been found (Moran 1986, Dayton 1989, Elner \& Vadas 1990, Walther et al. 2002, Smith \& Key 2004, Forcada et al. 2005). Anomalous months or years of the biology of an organism have been found (either seemingly independent of the environment, or reflecting an environmental anomaly), particularly in recruitment studies. This may, however, be an artefact of the relatively short time scales on which most ecological experiments are undertaken. An ideal feature of an organism's biology for investigating responses to environment is growth-many eukaryotes preserve a 
record in their bodies (e.g tree rings). Not only can variability be examined over small time scales but some fossils, including Antarctic Eocene bivalves (Buick \& Ivany 2004), preserve an environmental record over a wider temporal scale. Growth studies on polar biota have particularly strong potential because of high seasonality (increasing signal strength and clarity) and organism longevity (Arntz et al. 1994, Peck \& Brey 1996).

High latitude ecology has tried to answer the question of whether polar animals grow slowly by comparing Antarctic, temperate and tropical growth rates (Arntz et al. 1994). Fishes were an obvious initial study choice (e.g. Wohlschlag 1961, Burchett 1983, Everson 1984) since there was a considerable literature on warm water species for comparison. Rather than rings (such as in fish otolith bones) some animals produce growth check lines, which are external and can often be seen whilst the animals are still alive. Because of the strong seasonality of food and feeding in polar regions (Clarke 1988, Coma et al. 2000), growth check lines in molluscs (Lutz \& Rhodes 1980), bryozoans (Winston 1983), brachiopods (Brey et al. 1995b) and echinoids (Brey et al. 1995a) are typically pronounced in polar species. Photographic monitoring (Barnes 1995), calcein marking and stable isotope studies have confirmed growth check lines in many species to be annual (Brey \& Mackensen 1997, Brey et al. 1998, 1999, Smith et al. 2001). One brachiopod species has, however, been found to produce such lines with supra-annual frequency (1.8 times yearly in the brachiopod Liothyrella uva: see Peck \& Brey 1996). In most species, the number of growth check lines equals the colony age, and the volume of carbonate between 2 consecutive lines equals their annual production. Analysis of bryozoan growth check lines showed that growth was significantly greater in some years than in others, and that in some species this growth was linked to duration of food availability (Barnes 1995, Brey et al. 1998, 1999). The latitude link to growth seemed to be that polar growth was slower (or much slower) than in warmer water benthos (Dayton 1979, Arntz et al. 1994). Only a few species are known to grow relatively quickly (Dayton 1989, Rauschert 1991). The longerlived species enabled ecologists to investigate growth across several years or decades. Dayton's (1989) work on sponges and settlement panels showed that the growth and recruitment of some species might fluctuate over tens of years. Despite a variety of supra-annual signals (such as ENSO or ice: Murphy et al. 1995) in the oceanic environment and the potential of animals with growth check lines to reflect them, few studies, to our knowledge, have investigated this connection.
The bryozoan genus Cellarinella comprises heavily calcified, erect, suspension feeders. C. nutti is one of the more common and abundant species of this genus, and is endemic to the Southern Ocean. It is circumantarctic in distribution, and known from almost all well sampled regions from as far north as Bouvet Island (Hayward 1995). It is a typical member of its genus, and forms growth check lines (see Winston 1983). These lines have been confirmed as annual in both congenerics (Barnes 1995) and more distantly related (Brey et al. 1998, 1999) cheilostome species. The division of the colony into a series of segments by sequentially formed growth check lines enables the age of each colony to be determined. If the specimen is intact, the growth of each intersegment can be linked to a particular year by counting back from the year of collection. Herein we evaluate the value of the cheilostome bryozoan $C$. nutti as a model organism for reliable growth-time series. We use growth data to probe variability within-colony, within site, between site and between years. The main hypothesis we test is that growth varies insignificantly among years over the lifetime of a colony, i.e. approximately 2 decades.

\section{MATERIALS AND METHODS}

All samples were collected during the ANT XXI-2 expedition of PFS 'Polarstern' between November 2003 and January 2004 at 7 sites between 247 and $414 \mathrm{~m}$ depth and between latitudes $54^{\circ} 30^{\prime} \mathrm{S}, 03^{\circ} 14^{\prime} \mathrm{W}$ and $70^{\circ} 57^{\prime} \mathrm{S}, 10^{\circ} 33^{\prime} \mathrm{W}$. The sampling comprised 7 sites 1, 10, 100 and $>1000 \mathrm{~km}$ apart in the Southern Ocean (Fig. 1, Table 1). Collections were made using either a 1 or $3 \mathrm{~m}$ wide Agassiz trawl (1 cm mesh cod end) with an attached Rauschert dredge (1.5 mm mesh) or bottom trawl (Table 1). Trawls were dragged for 10 to $51 \mathrm{~min}$, and then brought up and sorted on the ship's deck. From each site, between 8 and 19 living specimens of the cheilostome bryozoan Cellarinella nutti were collected, cleaned and dried for analysis.

Table 1. Benthic trawls in the Weddell Sea, Southern Ocean, collecting bryozoan Cellarinella nutti. AGT: Agassiz trawl; RD: Rauschert dredge; BT: Bottom trawl

\begin{tabular}{|cccccc|}
\hline Station no. & Site & Position & $\begin{array}{c}\text { Depth } \\
(\mathrm{m})\end{array}$ & $\begin{array}{c}\text { Duration } \\
(\mathrm{min})\end{array}$ & Gear \\
\hline PS65/019-1 & 1 & $54^{\circ} 30^{\prime} \mathrm{S} 03^{\circ} 14^{\prime} \mathrm{W}$ & $247-260$ & 18 & $\mathrm{AGT}$ \\
PS65/069-1 & 2 & $70^{\circ} 26^{\prime} \mathrm{S} 08^{\circ} 37^{\prime} \mathrm{W}$ & $408-414$ & 51 & $\mathrm{RD}$ \\
PS65/090-1 & 3 & $70^{\circ} 56^{\prime} \mathrm{S} 10^{\circ} 32^{\prime} \mathrm{W}$ & $274-288$ & 20 & $\mathrm{AGT}$ \\
PS65/121-1 & 4 & $70^{\circ} 50^{\prime} \mathrm{S} 10^{\circ} 35^{\prime} \mathrm{W}$ & $268-274$ & 13 & $\mathrm{AGT}$ \\
PS65/161-1 & 5 & $70^{\circ} 56^{\prime} \mathrm{S} 10^{\circ} 31^{\prime} \mathrm{W}$ & $270-280$ & 11 & $\mathrm{AGT}$ \\
PS65/245-1 & 6 & $70^{\circ} 57^{\prime} \mathrm{S} 10^{\circ} 33^{\prime} \mathrm{W}$ & $318-337$ & 11 & $\mathrm{BT}$ \\
PS65/259-1 & 7 & $70^{\circ} 57^{\prime} \mathrm{S} 10^{\circ} 33^{\prime} \mathrm{W}$ & $300-333$ & 10 & $\mathrm{BT}$ \\
\hline
\end{tabular}




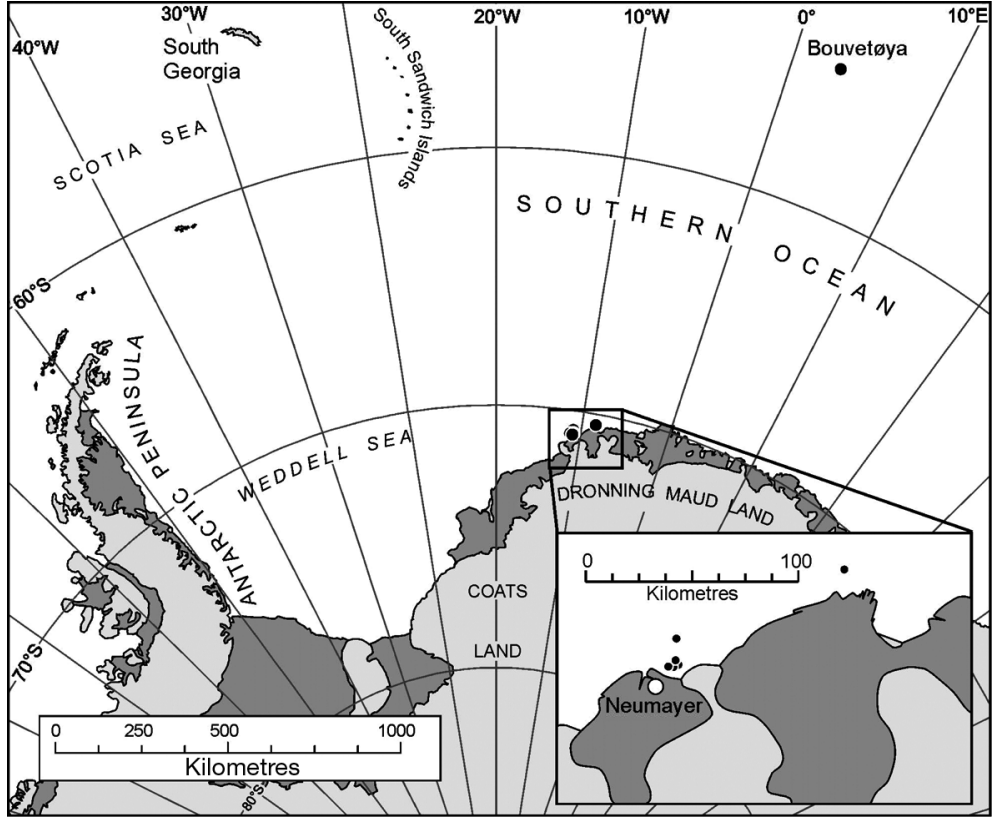

Fig. 1. Cellarinella nutti. Study region in the Southern Ocean, showing sites at Bouvetøya (Bouvet) Island and the SE Weddell Sea (magnified in inset). On scale of inset, 4 sites are so close together that they overlie each other

They were then ashed in a furnace $\left(480^{\circ} \mathrm{C}\right)$ for $24 \mathrm{~h}$ and reweighed to estimate AFDM.

The results were log transformed where necessary and tested for normality. Regression lines were fitted and the data subjected to ANOVA. To evaluate growth across years, we first calculated the line of best fit to the annual increment-at-age data for dry mass, for ash-free dry mass and for zooid number. We then computed the residuals of each increment from the appropriate model. Finally, we compared years by plotting the anomalies by year, 1-way ANOVA and post hoc Tukey tests.

\section{RESULTS}

We collected 93 specimens from 7 sites (Table 2). Nearly half (47.3\%) of the Cellarinella nutti colonies had grown from asexual (fragment) origins. The modal age of the C. nutti colonies examined was 9 yr (Fig. 2), although mean ages across sites were higher (Table 2). There was no significant age difference of $C$. nutti individuals

We examined the base of each Cellarinella nutti colony and recorded whether it had grown from a fragment of a previous colony (and was thus of asexual origin) or from a sexually produced larva. In colonies which have originated sexually, the base forms a smooth inverted cone just 1 or 2 zooids wide at the bottom. All unbroken (complete) colonies were selected as well as a few colonies lacking 1 or 2 segments. We recorded growth for years in which all segments were present. The age at first branching was recorded for each colony. In addition, for each colony, the following data were recorded: (1) the year and age of the colony at the time each segment was formed, (2) the number of zooids in the segment (using a binocular microscope), (3) the length of each segment in millimetres, (4) the dry mass of each segment, (5) the ash-free dry mass (AFDM) of each segment, and (6) any damage due to predation. To estimate dry mass and AFDM, we first excised each segment using a scalpel. Because of branching, there are multiple segments of the same age in some specimens, i.e. a typical specimen produces 1 segment each year for the first $5 \mathrm{yr}$, but then dichotomously divides to form 2 branches, thereafter producing 1 segment $\mathrm{yr}^{-1}$ on each branch $\left(=2\right.$ segments $\left.\mathrm{yr}^{-1}\right)$. After $\sim 3$ more yr it branches again, thereafter producing 1 segment $\mathrm{yr}^{-1}$ on each branch (= 4 segments $\mathrm{yr}^{-1}$ ). The annual increments calculated were the sum of all segments produced in a year. The segments of each age from each specimen were weighed on drying for $24 \mathrm{~h}$ at $60^{\circ} \mathrm{C}$ to estimate dry mass. among the 7 sites (ANOVA, $F_{6}=1.8, \mathrm{p}=0.11$ ). The mean onset of developing branching occurred at $5.3( \pm 0.4 \mathrm{SE})$ yr. Once branching occurred, different branches (of the same individual) generally grew at similar rates (intersegments were similar across different branches of the same colony), but the similarity of growth in branches of the same colony varied significantly between colonies (ANOVA, $F_{19}=2.7, \mathrm{p}<0.001$ ).

Branches of Cellarinella nutti grow at a mean rate of $3.44 \mathrm{~mm} \mathrm{yr}^{-1}( \pm 0.04 \mathrm{SE})$; this is the segment length. Typically, in the first year of growth colonies achieved $8.6 \mathrm{mg}$ dry mass $\mathrm{yr}^{-1}$, of which $8.3 \%$ (about $0.8 \mathrm{mg}$ ) was organic tissue (AFDM). Subsequent annual growth increments increased from $\sim 12.4 \mathrm{mg} \mathrm{CaCO}_{3} \mathrm{yr}^{-1}$ at $2 \mathrm{yr}$

Table 2. Cellarinella nutti. Sample size (n), mean age, number of colonies with asexual origins (growth from fragments) and mean age of branching. Standard deviations from means in parentheses

\begin{tabular}{|lrccc|}
\hline Site & $\mathrm{n}$ & $\begin{array}{c}\text { Age } \\
(\mathrm{yr})\end{array}$ & $\begin{array}{c}\text { No. with } \\
\text { asexual origin }\end{array}$ & $\begin{array}{c}\text { Mean age of } \\
\text { branching (yr) }\end{array}$ \\
\hline 1 & 12 & $9.8(3.2)$ & 5 & $5.2(1.9)$ \\
2 & 9 & $11.5(2.9)$ & 4 & $5.8(2.3)$ \\
3 & 18 & $11.2(3.5)$ & 9 & $5.3(1.8)$ \\
4 & 8 & $12.0(2.6)$ & 4 & $5.4(1.5)$ \\
5 & 17 & $13.1(4.8)$ & 9 & $5.5(2.1)$ \\
6 & 10 & $11.7(3.2)$ & 5 & $5.3(2.0)$ \\
7 & 19 & $12.5(4.3)$ & 8 & $5.0(1.9)$ \\
\hline
\end{tabular}




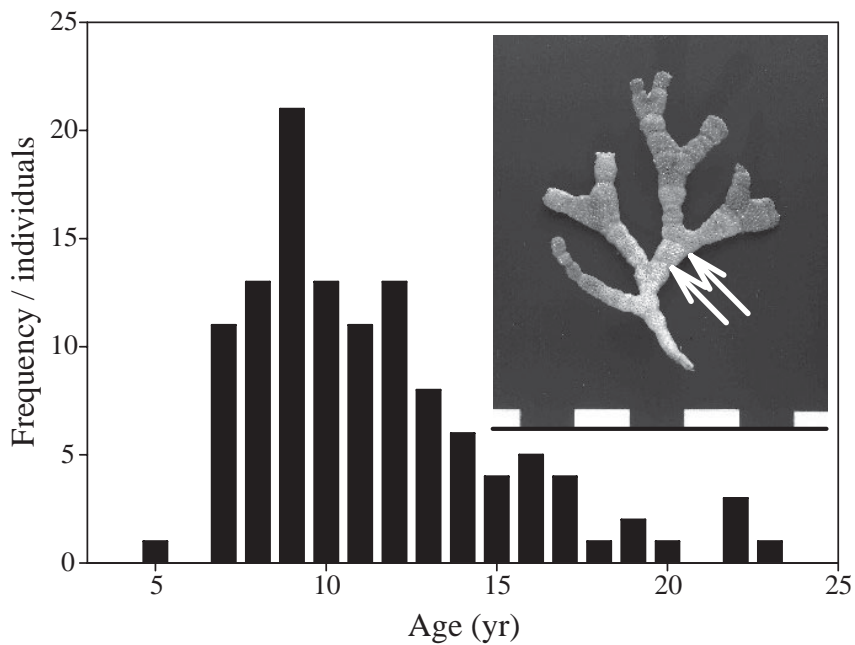

Fig. 2. Cellarinella nutti. Age-frequency of colonies in the Weddell Sea. Inset: 17 yr old colony, showing branching morphology (scale in $\mathrm{cm}$ ); arrows point to growth check lines

to $\sim 43 \mathrm{mg} \mathrm{CaCO}_{3} \mathrm{yr}^{-1}$ at $20 \mathrm{yr}$, and organic tissue was typically $\sim 5.5 \%$ of growth after Year 1 . Thus, at modal age, each $C$. nutti individual had precipitated over $182 \mathrm{mg} \mathrm{CaCO}_{3}$ and by 20 yr had precipitated nearly $580 \mathrm{mg}$. First-year colonies consisted of $\sim 18$ zooids, but the number of new zooids created rose each year, such that in their 20th year colonies produced $\sim 130$ zooids (summed production across all branches). Colonies may eventually exceed 1300 zooids in size. The cumulative increase in dry mass, AFDM and zooid number could be characterised by simple equations (see legend to Fig. 3). AFDM of Year 1 growth was elevated due to the colony growing (uncalcified) kenozooidal rootlets to provide support. There were strong relationships between dry mass, AFDM and zooid number and dry mass (Fig. 4).

Neither colony nor site were significant factors explaining variability in growth, but year emerged as highly significant (Table 3). Data were then analysed, pooling across colonies and sites. Lines of best fit to annual increments of dry mass, ash-free dry mass and zooid number by age were all (significant) linear regressions. The residuals from each of these regressions (dry mass, ash-free dry mass and zooid number

Table 3. Cellarinella nutti. ANOVA results for potential factors influencing variability in growth

\begin{tabular}{|lrcccc|}
\hline Source & df & SS & MS & $F$ & $\mathrm{p}$ \\
\hline Year & 21 & 0.60845 & 0.02897 & 1.80 & 0.015 \\
Colony & 13 & 0.17218 & 0.01324 & 0.83 & 0.634 \\
Site & 6 & 0.03605 & 0.00601 & 0.37 & 0.896 \\
Error & 1004 & 16.11780 & 0.01605 & & \\
Total & 1044 & 16.90933 & & & \\
\hline
\end{tabular}

detrended from age) significantly differed between years (ANOVA, all $F_{22}>3, \mathrm{p}<0.01$ ). Post hoc Tukey tests showed growth in 1999 to be significantly different from that in 1992 to 1996, in 2002 to be significantly different from that in the years 1991 to 1996 and in 2003 to be significantly different from the years 1988 to 2002 (all at the $\mathrm{p}<0.01$ level). Furthermore, this change was directional, forming a trend (Pearson correlation $=0.195, \mathrm{p}<0.01)$. Since 1984, annual growth of Cellarinella nutti has increased (irrespective of colony age), with the anomaly in 2003 being twice as high as in any other year measured (Fig. 5).
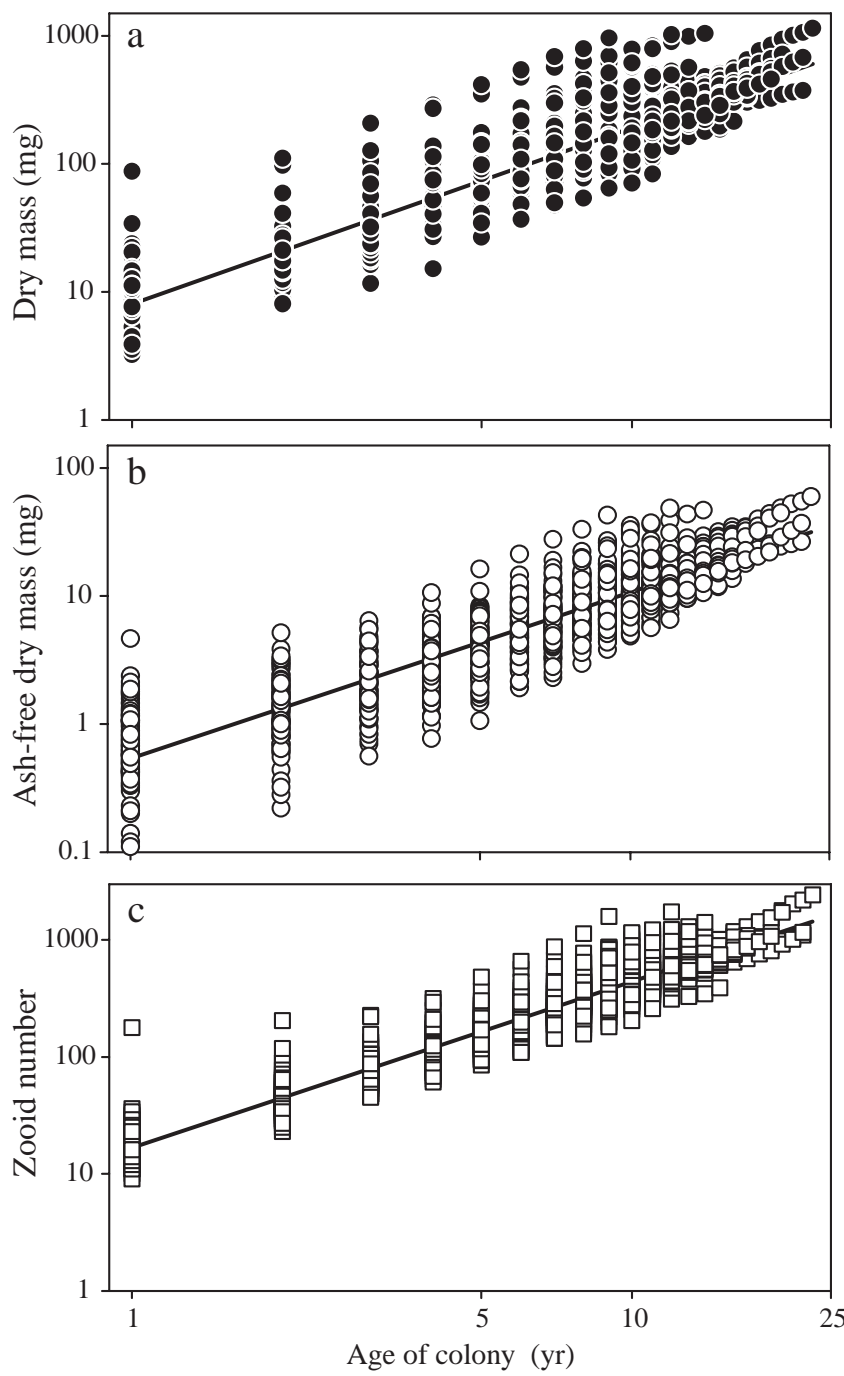

Fig. 3. Cellarinella nutti. Cumulative (whole colony) growth as (a) colony dry mass, (b) colony ash-free dry mass and (c) zooid number as a function of age. Data are means \pm SE $(n \geq 5$ for each point). Relationships are first order regressions; formulae and significance are: $\log ($ dry mass $)=0.928+1.423$ $\log$ (age), $\mathrm{r}^{2}=0.99, F=19436, \mathrm{p}<0.001 ; \log$ (ash-free dry mass) $=-0.228+1.343 \log ($ age $), \mathrm{r}^{2}=0.99, F=2452, \mathrm{p}<0.001$; $\log ($ zooid number $)=1.195+1.514 \log ($ age $), r^{2}=0.99, F=9133$, $\mathrm{p}<0.001$ 


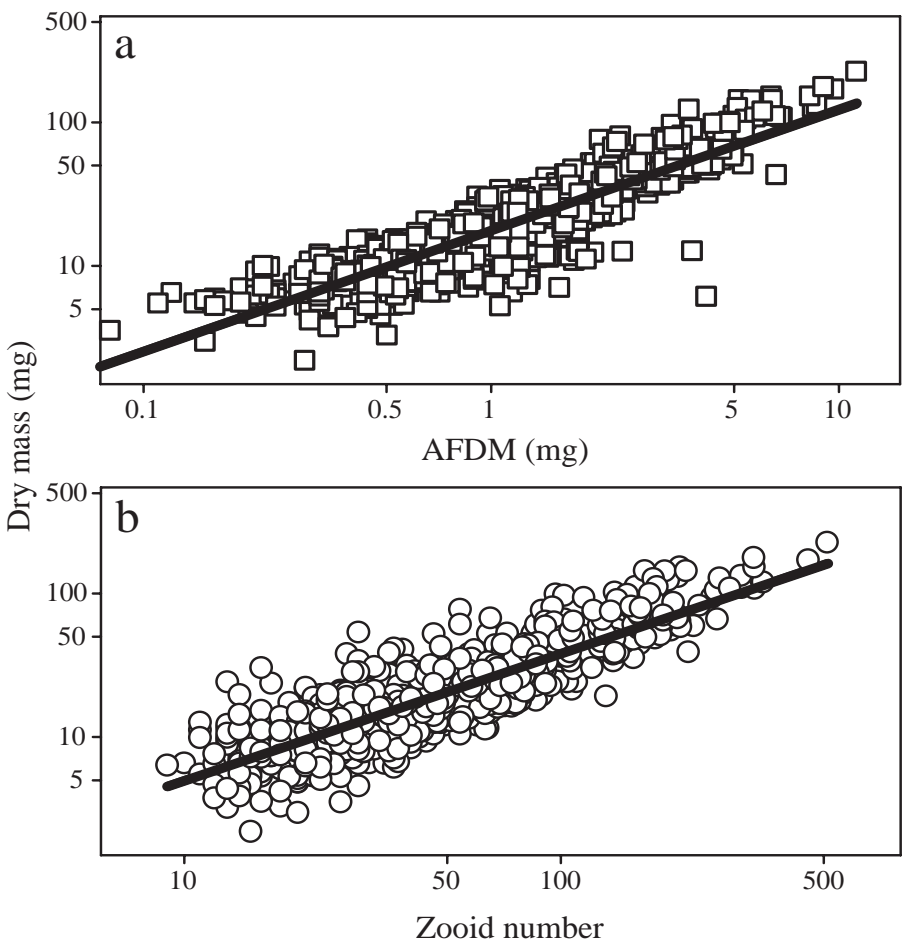

Fig. 4. Cellarinella nutti. Relationships between annual segment (not colony), growth (dry mass) and (a) organic growth $(\mathrm{AFDM})$ and (b) zooid number. (a) log dry mass $=1.24+0.84$ $\log$ AFDM, $\mathrm{r}^{2}=0.79, F_{1}=4485, \mathrm{p}<0.001$; (b) log dry mass $=$ $0.19+0.88 \log$ zooid number, $\mathrm{r}^{2}=0.75, F_{1}=3462$

Mechanical damage of some specimens was recorded, as was some evidence of repair of prior branch breakage. However, no damage to colonies was observed that was considered attributable to predation. Thus, it is considered that predation was not a factor influencing differences in numbers of zooids or mass of segments. No overgrowth was observed on any of the study colonies.

\section{DISCUSSION}

\section{Within-colony, between-colony, site, year and species variability}

We examined specimens of Cellarinella nutti, from amongst the most northerly and southerly points of the Southern Ocean at (3 to $10^{\circ}$ longitude) across sites varying distances apart. At the smallest scale, we found varying growth rates and damage in different branches within colonies of $C$. nutti, as found by Smith \& Key (2004) in the New Zealand bryozoan Adeonellopsis sp. This variability was minor, however, and we found no significant effect of colony or site (Table 3 ) in our analyses despite between-site distances ranging
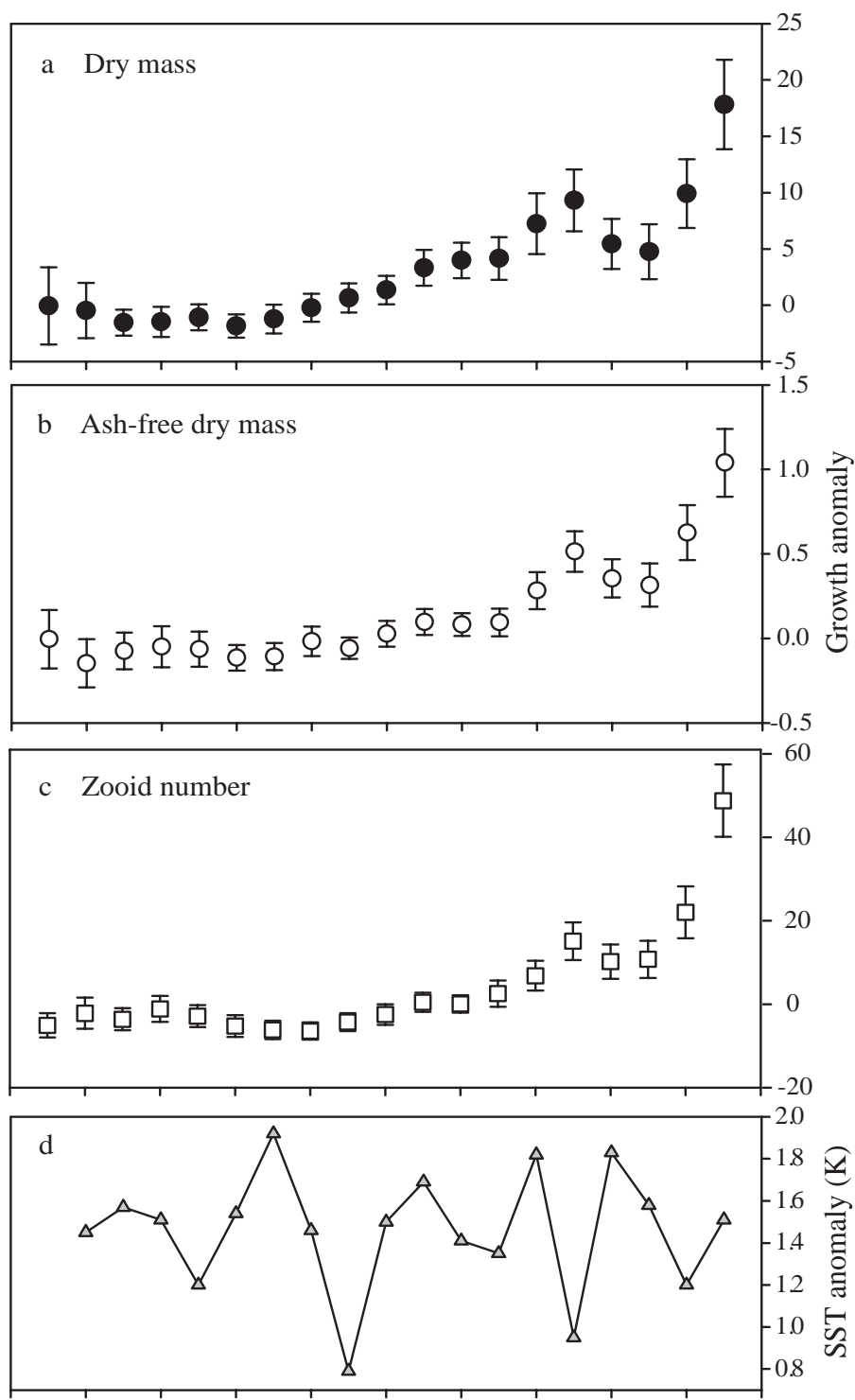

$\begin{array}{lllllllllll}1984 & 1986 & 1988 & 1990 & 1992 & 1994 & 1996 & 1998 & 2000 & 2002 & 2004\end{array}$ Year

Fig. 5. Anomalies in $(\mathrm{a}, \mathrm{b}, \mathrm{c})$ growth of bryozoan Cellarinella nutti and in (d) sea-surface temperature (SST) (associated with the El Niño Southern Oscillation) by year: SST anomalies from Forcada et al. (2005). Growth (means \pm SE) shown in terms of (a) dry mass, (b) ash-free dry mass and (c) zooid number on segments

from 1 to $1000 \mathrm{~km}$ apart (Fig. 1). Such robustness to spatial variability makes our species ideal for investigation of temporal variability. Growth rate values are now known for a number of mid- to high latitude, southern, erect bryozoan species (Table 4). In none of these species has spatial variability been investigated, although Barnes \& Arnold (2001) found significant spatial variability in 2 encrusting Antarctic species (Inversiula nutrix and Celleporella bougainvillei) along a lat- 
Table 4. Growth and age of erect bryozoan species by region. Growth shown as colony length extension and calcium carbonate production

\begin{tabular}{|llcccl|}
\hline Region & Species & $\begin{array}{c}\text { Length } \\
\left(\mathrm{mm} \mathrm{yr}^{-1}\right)\end{array}$ & $\begin{array}{c}\text { Mass } \\
\left(\mathrm{mg} \mathrm{CaCO}_{3} \mathrm{yr}^{-1}\right)\end{array}$ & $\begin{array}{c}\text { Max. } \\
\text { age (yr) }\end{array}$ & Source \\
\hline Antarctic & Cellarinella nutti & 3.44 & 28.9 & 23 & This study \\
& Cellarinella watersi & 5 & 600 & 09 & Barnes (1995) \\
& Isosecuriflustra tenuis & 2.5 & 160 & 26 & Barnes (1995) \\
& Nematoflustra flagellata & 7 & 800 & 26 & Barnes (1995) \\
& Melicerita obliqua & 4.5 & 10.7 & 45 & Brey et al. (1998), Bader \& Schäfer (2004) \\
& Cellaria incula & 8.2 & 2600 & 14 & Brey et al. (1999) \\
New Zealand & Adeonellopsis sp. & 6.9 & 23700 & 20 & Smith et al. (2001) \\
& North NZ species & & $25-740$ & & Smith \& Nelson (1994) \\
& Cellaria sinuosa & 40 & $\sim 3000$ & 1.5 & Bader (2000) \\
& Pentapora foliacea & 20 & & 10 & Pätzold et al. (1987) \\
& Flustra foliacea & 12 & 6000 & 12 & Stebbing (1971) \\
& Pennipora anomalopora & 3 & & 35 & Taylor \& Voigt (1999) \\
\hline
\end{tabular}

itudinal gradient. Our study sites included areas further north and south of the Barnes \& Arnold (2001) study, comparisons are confounded by differences in both the depth of water (40 vs. $400 \mathrm{~m}$ ) and type of organism (encrusting vs. erect) between their study and ours. In accordance with other investigators (e.g. Barnes 1995, Brey et al. 1999, Smith et al. 2001, Bader \& Schäfer 2004, Smith \& Key 2004), we detected between-year (as well as seasonal) variability in growth rate. In the case of $C$. nutti, nearly $10 \%$ more zooids and $>16 \%$ more dry mass were accumulated in the most productive compared to the least productive years. Over the $20 \mathrm{yr}$ from 1984 to 2003, the last year (2003) was the most productive. It is possible that the magnitude of growth was particularly high in 2003 because this was our last sampling year and resorption of tissue into the final growth 'band' had perhaps occurred during the non-growing season. We consider this unlikely, as measurements of the congeneric species C. watersi from 1988 to 1992 did not reveal 1992 (the last year measured) as a year of anomalously high production (Barnes 1995).

A potential source of error would be no growth in 1 or more years. If this had happened, then segments would be missing for this year across branches and colonies and 2 problems would arise. Firstly, our mean values of growth would be artificially high, and secondly (and more seriously), back-counting along segments would incorrectly assign segments to years. Whilst we cannot rule this out as a source of error, we feel that a year of zero growth would be unlikely, except following an obvious environmental catastrophe.

Cellarinella nutti grows slowly-not only in accordance with bryozoan growth in general, but also compared to other, similar, Antarctic bryozoans (Table 4). In the most productive study year (2003), the most productive individuals grew at a rate of $\sim 52 \mathrm{mg}$ dry mass $\mathrm{yr}^{-1}$, nearly double the rate typical for this species, but still 1 order of magnitude less than typical values measured for the related Antarctic species $C$. watersi (Barnes 1995) or Cellaria incula (Brey et al. 1999). The most productive, C. watersi at Signy Island (9 yr old individuals) were growing at a rate of nearly $2 \mathrm{~g}$ dry mass $\mathrm{yr}^{-1}$, while the most productive individuals of the fastest growing of reported Antarctic species to date, Nematoflustra flagellata, grow at twice this rate (4 $\mathrm{g}$ dry mass $\mathrm{yr}^{-1}$, see Barnes 1995). Since Dayton's (1979) study of sponge growth rates, work on a wide variety of taxa in the Antarctic has revealed their rate of growth to be considerably lower than comparable representatives at low latitude (Arntz et al. 1994). Thus, C. nutti seems to resemble other Antarctic benthos with respect to growth rate, i.e. 'life in the slow lane'. Although it does indeed seem to grow more slowly than other Antarctic bryozoans measured to date, we believe it is probably the most typical bryozoan measured, since previous studies (Barnes 1995, Brey et al. 1998, 1999, Barnes \& Arnold 2001, Bader \& Schäfer 2004) all investigated pioneer species, mainly (in some cases) because these were fast growing.

\section{Signals of change in the Southern Ocean on ecological time scales}

Rapidly changing patterns in phenology are being observed in global terrestrial and freshwater environments (Walther et al. 2002). The last few years have produced a series of revelations on significant physical changes in the Southern Ocean (Gille 2002, Clarke \& Harris 2003) and coincident changes in water-column productivity (Atkinson et al. 2004, Forcada et al. 2005), with the current study revealing changes on the 
seabed as well. We found no obvious link between the annual growth increments of Cellarinella nutti and ENSO patterns (Fig. 5). However, 2002 was an anomalously warm year in the Weddell Sea (A. A. Bianchi \& I. Schloss pers. comm.), and perhaps had a direct or indirect (through influences on phytoplankton production) influence on 2003, which was a year of exceptionally high growth for $C$. nutti. Monitoring long-term phytoplankton abundance and resampling $C$. nutti over the next couple of years might confirm whether the extremely high growth rate in 2003 was strongly linked to phytoplanktonic abundance, and if growth in the Antarctic slow lane is about to increase drastically.

\section{Reliable externally visible predictor of growth rate}

Can growth be reliably calculated in an animal with clearly defined annual growth check lines, by remote measurement alone? Brey et al. (1998) found segment area a much better predictor of growth than simple segment length. We tried an alternative method. Our counts of the number of zooids (modules) making up each increment of the colony resembled dry mass and AFDM patterns closely. Our zooid count method has an advantage over Brey et al.'s (1998) area method, as our images require no scale bar, involve no parallax issues, and (requiring no measurement) should have less associated error. Counting thousands of zooids is labour intensive, but it has advantages over the most popular method for measuring growth variability, i.e. oxygen isotope ratios (Corfield 1995, Jones \& Quitmyer 1996, Smith et al. 2001, Bader \& Schäfer 2004; and Y. Bone \& N. P. James unpubl. data), as it is nondestructive and can be carried out with high resolution images. Smith \& Key (2004) demonstrated the power of the oxygen isotope technique in revealing detailed patterns of annual variability of growth and ENSO signals using just 1 colony of the southern New Zealand bryozoan Adeonellopsis sp.

\section{Model benthic organism for investigation of short- term ecological responses to climate change}

Antarctica and the Southern Ocean are already undergoing major changes in climate, but currently we know very little about marine animal responses to such shifts and, to date, few model taxa have been identified. New analyses of interannual patterns in longterm data sets are revealing some significant changes in the physical and biological characteristics of the Southern Ocean. There are signs of decreasing duration of surface fast-ice (Clarke \& Harris 2003), deep water warming (Gille 2002), declines in krill and increases in salp populations (Atkinson et al. 2004), and changes in the reproductive success of higher predators (Forcada et al. 2005). Our results have revealed significant growth increases in a benthic suspension feeder over 2 decades. While our data concern only a single bryozoan species, we believe that our findings, like those of Atkinson et al. (2004) and Forcada et al. (2005), have a wide relevance to polar productivity patterns. Clearly, the value of such data is linked to the general applicability of the organism studied. Our model animal, the phytoplanktonconsuming bryozoan Cellarinella nutti, is ideal in many ways: its external morphology reveals its age, patterns of annual growth and skeletal evidence of its origins (i.e. a sexually produced ancestrula). Cellarinellid bryozoans can be extremely abundant in shelf environments (Fig. 6), sometimes approaching 99\% cover, making this type of animal ecologically important and representative (Bullivant 1967, Winston 1983, Barnes 1995, Teixido et al. 2004). The rigid, erect (cellarinellid type), bryozoan growth form is widely represented from shallow waters to deep shelf depths, from the tropics to the poles and from Mesozoic to recent environments (McKinney \& Jackson 1991, Taylor \& Wilson 2003). There are, however, factors which limit the general applicability of data from C. nutti, such as the near absence of congenerics and confamilials outside the Southern Ocean (Hayward 1995) and its easy breakage when collected by trawling.

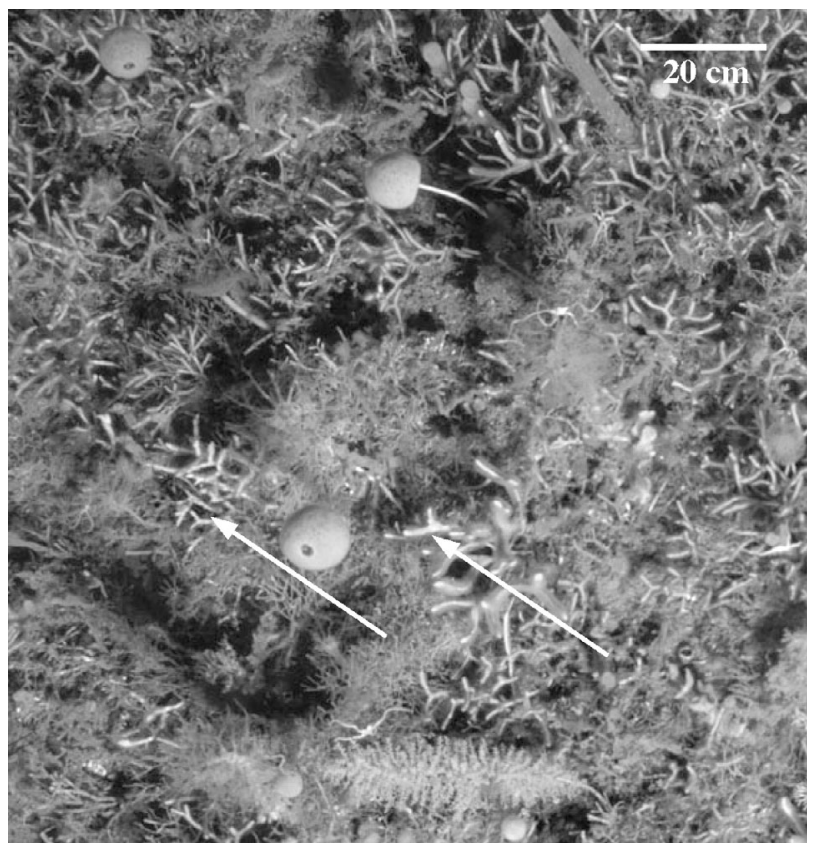

Fig. 6. Cellarinellid bryozoans (arrows) dominating a benthic community at $159 \mathrm{~m}$ in the Weddell Sea (photograph courtesy of J. Gutt). Scale is approximate 


\section{CONCLUSIONS}

In summary, the bryozoan Cellarinella nutti appears to be a useful model representative of the benthos for investigation of climate change over the scale of its life span $(20 \mathrm{yr})$. In terms of growth rate, it is a typical Antarctic zoobenthic suspension feeder in that it is a long-lived slow-grower. Counts of the number of modules (zooids) produced each year were highly correlated with dry mass and ADFDM measures of growth. Thus, counting of zooids measures growth as succesfully as these traditional methods, with the additional advantage that it is a non-invasive method that can even be carried out using high resolution photographs. Our analyses of annual variability in productivity revealed both a strong trend of increasing growth since about 1990, and anomalously high production in 2003. Spatial variability was insignificant on scales from 1 to $1000 \mathrm{~km}$ so do confound patterns in time. Supra-annual trends of potential responses to climate change have been previously reported in populations of pelagic and surface-dwelling consumers of the Southern Ocean. Growth increases in C. nutti are unlikely to be directly linked to the small degree of deep-water warming reported (Gille 2002), but may be indirectly related to warming effects on primary productivity. We suggest that collections of animals such as cellarinellid bryozoans would provide some powerful insights into benthic responses to yearly and decadal changes in the Southern Ocean.

Acknowledgements. We thank W. E. Arntz (Alfred Wegner Institute, Germany), who enabled Katrin Linse's participation in ANT XXI-2, and the helpful colleagues and ship crew of PFS 'Polarstern'. We also thank Drs. L. S. Peck, T. Brey and 4 anonymous referees for comments on an early draft of the manuscript.

\section{LITERATURE CITED}

Arntz WE, Brey T, Gallardo VA (1994) Antarctic zoobenthos. Oceanogr Mar Biol Annu Rev 32:241-304

Atkinson A, Siegel V, Pakhomov E, Rothery P (2004) Longterm decline in krill stock and increase in salps within the Southern Ocean. Nature 432:100-103

Bader B (2000) Life cycle, growth rate, and carbonate production of Cellaria sinuosa. In: Herrera Cubilla A, Jackson JBC (eds) Proc 11th Int Bryozoology Assoc Conf. Smithsonian Tropical Research Institute, Balboa, p 136-144

Bader B, Schäfer P (2004) Skeletal morphogenesis and growth check lines in the Antarctic bryozoan Melicerita obliqua. J Nat Hist 38:2901-2922

Barnes DKA (1995) Seasonal and annual growth in erect species of Antarctic bryozoans. J Exp Mar Biol Ecol 188:181-198

Barnes DKA, Arnold RJ (2001) A growth cline in encrusting benthos along a latitudinal gradient within Antarctic waters. Mar Ecol Prog Ser 210:85-91

Brey T, Mackensen A (1997) Stable isotopes prove shell growth bands in the Antarctic bivalve Laternula eliptica to be formed annually. Polar Biol 17:465-468

Brey T, Pearse JS, Basch L, McLintock JB, Slattery M (1995a) Growth and production of Sterechinus neumayeri (Echinoidea: Echinodermata) in McMurdo Sound, Antarctica. Mar Biol 124:279-292

Brey T, Peck LS, Gutt J, Hain S, Arntz W (1995b) Population dynamics of Magellania fragilis, a brachiopod dominating a mixed-bottom macrobenthic assemblage on the Antarctic shelf. J Mar Biol Assoc UK 75:857-870

Brey T, Gutt J, Mackensen A, Starmans A (1998) Growth and productivity of the high Antarctic bryozoan Melicerita obliqua. Mar Biol 132:327-333

Brey T, Gerdes D, Gutt J, Mackensen A, Starmans A (1999) Growth and age of the Antarctic bryozoan Cellaria incula on the Weddell Sea shelf. Antarct Sci 11:408-414

Buick DP, Ivany LC (2004) 100 years in the dark: extreme longevity of Eocene bivalves from Antarctica. Geology 32: 921-924

Bullivant JS (1967) Ecology of the Ross Sea benthos. N Z J Mar Freshw Res 32:49-75

Burchett MS (1983) Age and growth of the Antarctic fish Notothenia rossii from South Georgia. Br Antarct Surv Bull 60:45-61

Clarke A (1988) Seasonality in the Antarctic marine environment. Comp Biochem Physiol B 90:461-473

Clarke A, Harris CM (2003) Polar marine ecosystems: major threats and future change. Environ Conserv 30:1-25

Coma R, Ribes M, Gili JM, Zabala M (2000) Seasonality in coastal benthic ecosystems. Trends Ecol Evol 15:448-453

Corfield RM (1995) An introduction to the techniques, limitations and landmarks of carbonate oxygen isotope palaeothermometry. Spec Publ Geol Soc Lond 83:27-43

Dayton PK (1979) Observations of growth, dispersal and dynamics of some sponges in McMurdo sound, Antarctica, and its biological effects. In: Levian C, Bourny-Esnault N (eds) Sponge biology. Centre National de la Recherche Scientifique, Paris, p 271-283

Dayton PK (1989) Interdecadal variation in an Antarctic sponge and its predators from oceanographic climate shifts. Science 245:1484-1486

Elner RW, Vadas RL (1990) Inference in ecology: the sea urchin phenomenon in the northwestern Atlantic. Am Nat 136:108-125

Everson I (1984) Fish biology. In: Laws RM (ed) Antarctic ecology. II. Academic Press, London, p 491-532

Forcada J, Trathan P, Reid K, Murphy EJ (2005) The effects of global climate variability in pup production of Antarctic fur seals. Ecology 86:2408-2417

Gille ST (2002) Warming of the Southern Ocean since the 1950s. Science 295:1275-1277

Hayward PJ (1995) Antarctic cheilostomatous Bryozoa. Oxford University Press, Oxford

Hodgson DA, Noon PE, Vyverman W, Bryant CL and 8 others (2001) Were the Larsemann Hills ice-free through the last glacial maximum? Antarctic Sci 13: 440-454

Jackson JBC, Kirby MX, Berger WH, Bjorndal KA and 15 others (2001) Historical overfishing and the recent collapse of coastal ecosystems. Science 293:629-638

Jones DS, Quitmyer IR (1996) Marking time with bivalve shells: oxygen isotopes and season of annual increment formation. Palaios 11:340-346

Lutz RA, Rhodes DC (1980) Growth patterns within the molluscan shell: an overview. In: Rhodes DC, Lutz RA (eds) Skeletal growth of aquatic organisms. Plenum Press, New York, p 203-254

McKinney FK, Jackson JBC (1991) Bryozoan evolution. University of Chicago Press, Chicago, p 1-238 
Moran PJ (1986) The Acanthaster phenomenon. Oceanogr Mar Biol Annu Rev 24:379-480

Murphy EJ, Clarke A, Simon C, Priddle J (1995) Temporal variation in Antarctic sea-ice: analysis of a long term fastice record from the South Orkney islands. Deep-Sea Res I 42:1045-1062

Pätzold J, Ristedt H, Wefer G (1987) Rate of growth and longevity of a large colony of Pentapora foliacea (Bryozoa) recorded in their oxygen isotope profiles. Mar Biol 96: 535-538

Peck LS, Brey T (1996) Bomb signals in old Antarctic brachiopods. Nature 380:207-208

Rauschert M (1991) Ergebnisse der faunistischen Arbeiten im Benthal von King George Island (Südshetlandinseln, Antarktis). Ber Polarforsch 76:1-75

Smith AM, Key MM Jr (2004) Controls, variation, and a record of climate change in detailed stable isotope record in a single bryozoan skeleton. Quat Res (Orlando) 61:123-133

Smith AM, Nelson CS (1994) Calcification rates of rapidly colonizing bryozoans in Haukuri Gulf, northern New Zealand. N Z J Mar Freshw Res 28:227-234

Smith AM, Stewart B, Key MM, Jamet CM (2001) Growth and carbonate production by Adeonellopsis (Bryozoa: Cheilo-

Editorial responsibility: Otto Kinne (Editor-in-Chief), Oldendorf/Luhe, Germany stomata) in Doubtful Sound, New Zealand. Palaeogeogr Palaeoclimatol Palaeoecol 175:201- 210

Stebbing ARD (1971) Growth of Flustra foliacea (Bryozoa). Mar Biol 9:267-273

Taylor PD, Voigt E (1999) An unsually large cyclostome (Pennipora anomalopora) from the upper Cretaceous of Maastricht. Bull Inst R Sci Nat Belg Sci Terre 69:165-171

Taylor PD, Wilson MA (2003) Palaeoecology and evolution of marine hard substrate communities. Earth-Sci Rev 62:1-103

Teixido N, Garrabou J, Gutt J, Arntz WE (2004) Recovery in Antarctic benthos after iceberg disturbance: trends in benthic composition, abundance and growth forms. Mar Ecol Prog Ser 278:1-16

Walther GR, Post E, Convey P, Menzel A and 5 others (2002) Ecological response to recent climate change. Nature 416 : 389-395

Williams M, Dunkerley D, DeDeckker P, Kershaw P, Chappell J (1998) Quaternary environments. Arnold Hodder, London

Winston JE (1983) Patterns of growth, reproduction and mortality in bryozoans from the Ross Sea, Antarctica. Bull Mar Sci 33:688-702

Wohlschlag DE (1961) Growth of an Antarctic fish at freezing temperatures. Copeia 1961:11-18

Submitted: July 4, 2005; Accepted: October 13, 2005

Proofs received from author(s): April 26, 2006 